MATEC Web of Conferences 47, 03002 (2016)

DOI: $10.1051 /$ matecconf/20164703002

(C) Owned by the authors, published by EDP Sciences, 2016

\title{
Structural Equation Modelling in Behavioral Intention to Use Safety Helmet Reminder System
}

\author{
Naida Rosli ${ }^{1, a}$, Kamarudin Ambak ${ }^{1}$, Basil David Daniel ${ }^{1}$ and Mohd Erwan Sanik ${ }^{1}$ \\ ${ }^{1}$ Smart Driving Research Centre, Universiti Tun Hussein Onn Malaysia, 86400 Parit Raja, Johor, Malaysia
}

\begin{abstract}
Motorcycle is one of private transportation which has been widely used in many countries including Malaysia. However, motorcycles are the most dangerous form of motorized transport. Royal Malaysian Police (PDRM) statistics recorded that motorcycle is the highest vehicle $(45.9 \%)$ involved in traffic accident compared to other vehicles. The potential cause of the death to the motorcyclist was due to the head injury. One of strategy to mitigate this problem is through proper usage of safety helmet. Therefore, this paper was introduce a new approach on motorcyclist safety by using the Technology Acceptance Model (TAM) with additional determinants that contribute to behavioral intention and to increase the proper usage of safety helmets among Malaysian motorcyclists. The Structural Equation Modelling (SEM) was used to test the structural TAM proposed. The evaluation for structural model showed the goodness of fit indices are excellent fit. This study found that perceived ease of use, perceived usefulness and social norm are significant towards behavioral intention to use Safety Helmet Reminder System (SHR).
\end{abstract}

\section{Introduction}

Currently, many people use motorcycles for their daily activities such as going to work or school. This is due to the fact that motorcycles are compact, agile, consume less fuel and affordable to buy and maintain than automobiles [1].Therefore, motorcycle is one of private transportation which has been widely used in many countries including Malaysia. Besides that, motorcycle is the dominating transport mode as a motorization is growing fast in Asian [2].

Despite the fact that motorcycles have more attraction and advantages than other vehicles do, they are still riskier than other transportation. Motorcycles are the most dangerous form of motorized transport [3]. Majority of road accidents fatalities involve motorcyclist, constituting more than $50 \%$ of the total number of fatalities [2]. Ambak et al. [4] also found that motorcycle is known as to be vulnerable road users in term safety-risk exposure and instability compared to other vehicles. Based on statistical report of road accidents in Malaysia 2012 by Royal Malaysia Police (PDRM) [5] shows that motorcycle is the highest vehicle $(45.9 \%)$ involved in a traffic accident compared to car (30.1\%), lorry $(10.3 \%)$, bus $(1.59 \%)$, van $(1.93 \%)$ and others $(10.35 \%)$.

In addition, it is reported that the potential cause of death to the motorcyclists was due to head injury. Pang et al. [6] highlighted that $62.9 \%$ of vital organ injury causing deaths among the motorcyclists are due to head injuries. Futhermore, Abdul Manan and Varhelyi [2] stated that injury

\footnotetext{
${ }^{a}$ Corresponding author : kamardin@uthm.edu.my
} 
caused in motorcycle fatalities is mainly to the head. Therefore, Ambak et al. [4] suggested that one of strategy to mitigate this problem is through proper usage of safety helmet. Motorcycle helmet is the best shielding equipment that is possible to wear while riding a motorcycle, being most effective means of protection offered to motorcyclists [7]. However, Abdul Manan and Varhelyi [2] reported that $75 \%$ or motorcyclist involved in road accidents wore helmets. Jaafar et al. [8] which states that motorcyclists who wears safety helmets are the highest numbers of fatalities from the overall road accidents in Malaysia. There are several possible reasons why motorcyclists with their helmets on are still suffering head injuries, (1) Motorcyclists do not wear them properly either the helmets' sizes are too large or they are not fastened properly (2) use unstandardized motorcycle helmets (3) Motorcyclists wear helmets that have been used for too long (4) riding motorcycle in high speed. Jaafar [9] indicated that in motorcycle accidents, $23.3 \%$ involving the helmet coming off during the impact that causing $25.2 \%$ of motorcyclist suffering severe head injuries. The properly safety helmet use can reduce injuries by $25 \%$ [9].

Therefore, the aim of this study is to introduce a new approach on motorcyclist safety by using the Technology Acceptance Model (TAM) with additional determinants that contribute to behavioral intention and to increase the proper usage of safety helmets among Malaysian motorcyclists.

\section{Reference Model and Hypothesis}

\subsection{Technology acceptance model}

Technology Acceptance model was widely used in previous study to examine user perception and acceptance towards new system or technology. The Technology Acceptance Model was developed by Davis (1986). This model is grounded in both Theory Reasoned Action (TRA) and Theory Planned Behavior (TPB) [10,11]. The factor in the model, namely perceived usefulness (PU), perceived ease of use (PEOU) and attitudes toward usage (ATU), represents characteristic of the system [10]. While, the behavioral intention to use is an important factor that determines whether users will actually utilize the system [12].

Perceived Usefulness refer to the degree to which an individual believes that using a particular system would enhance his or her job performances" [10]. While peceived ease of use indicated that the degree to which an individual believes that using a particular system would be free of physical and mental effort" [10].

There have a two additional variables in this study to determine the behavioral intention towards using safety helmet reminder system. There are social influence and perceived safety. Social influence is defined as the degree which an individual believes that other people whose opinion is important to himself/herself think the same way about using a new system [13]. While perceived safety is defined as the degree to which an individual believes that using a system will affect his or her well-being [13]

\subsection{Hypothesis}

The construct in TAM was used to know the relationship between perceived usefulness, perceived ease of use, behavioral intention, social influence and perceived safety against exogenoues variable which is (behavioral intention to use safety helmet reminder system) that can affect the helmet use among motorcyclist. Therefore, the hypothesis was test to know the significance of this constructs. H1: Perceived usefulness significant positive impact on behavioral intention to use SHR among motorcyclist. H2: Perceived ease of use significant positive impact on perceived usefulness for using SHR among motorcyclist. H3: Behavioral intention to use SHR significant impact on helmet use among motorcyclist. H4: Social norm significant positive impact on behavioral intention to use a SHR among motorcyclist. H5: Social norm significant positive impact on perceived usefulness for using the SHR among motorcyclist. H6: Perceived safety significant positive impact on behavioral intention to use a SHR among motorcyclist. 


\section{Methodology}

\subsection{Instrument and measurement}

This study utilized the survey questionnaire form as the main data instrument. The questionnaire was designed based on Technology Acceptance Model (TAM) and adapted from a few previous literature. The questionnaire was divided into 5 sections. A seven likert point scale was used to examine the agreement of respondents towards Safety Helmet Reminder System (SHR).

\section{2 Data collection}

The quantitative data were collected by self-administered questionnaire form that distribute face to face among motorcyclists in Parit Raja, Batu Pahat, Johor. Only voluntarily respondents were asked to answer the questionnaire form based on their perception towards Safety Helmet Reminder System (SHR). Data collection took place from first May until end of July 2013.

\subsection{Sampling method and sample size}

This study used the stratified random sampling method approach to obtain the sample of respondents. The population was chosen among motorcyclist in Johor area and the strata in Parit Raja, Johor. The estimation of population in this research was taken from the total of the number motorcycle registered in Johor state. To determine the sample size for this study, the Formula of Cochran (1977) was used because this formula is suitable to determine the sample size with having the data categorical and continuous data. The total minimum of sample size required from the Cochran's formula calculation is 118. However, this study chosen 300 respondents as a sample size. This is because Weston and Goore [14] has stated that minimum sample size required for Structural Equation Modelling is 200. Then, the questionnaire were processed with the aid of SPSS version 22 while for the Structural Equation Modelling AMOS software was used to test the structural model.

\section{Results and Discussion}

\subsection{Descriptive analysis}

Table 1 present the descriptive statistics based on 300 respondents among motorcyclist. Most of the participant's aged varied between 21 to 29 years old (40.0\%) with majority of them was male $(72.3 \%)$ compared to female $(27.7 \%)$. This have been indicated in previous study that singles and young males are the highest group in of motorcyclist in Malaysia [11]. We also noted that most of them attained education from higher institution $(59.7 \%)$ and work in private sector $(41.7 \%)$ with monthly income RM3001 and above (33.3\%). Besides that, most of respondents possess full driving licenses (74.3\%) and have riding experience 10 years and above (63.3\%). Regarding experience with road accident, majority of respondents have an experience with road accident $(69.3 \%)$ with frequency involvement 3 times and more (36.7\%). The data clearly indicated that majority of respondents possessed full face helmet (283\%). Ambak et al. [15] study also indicate that most of Malaysian motorcyclist owned fullshell helmets. While Ambak et al. [16] stated that majority of motorcyclist in Malaysia possessed helmets that have safety features and meet the standard requirements set by the authorities.

\subsection{Reliability and correlation analysis}

The reliability test was performed for all items selected in the proposed model by using Alpha Cronbach coefficient. Alpha Cronbach coefficient between .65 to .95 is considered satisfactory [17]. 
Table 1. Characteristic of the respondents ( $\mathrm{N}=300)$.

\begin{tabular}{|c|c|c|}
\hline Demographic & Frequency & $(\%)$ \\
\hline \multicolumn{3}{|l|}{ Age (Years) } \\
\hline 20 and below & 32 & 10.7 \\
\hline 21 to 29 & 120 & 40.0 \\
\hline 30 to 39 & 86 & 28.7 \\
\hline 40 to 49 & 44 & 14.7 \\
\hline 50 and above & 18 & 6.0 \\
\hline \multicolumn{3}{|l|}{ Gender } \\
\hline Male & 217 & 72.3 \\
\hline Female & 83 & 27.7 \\
\hline \multicolumn{3}{|l|}{ Marital Status } \\
\hline Single & 133 & 44.3 \\
\hline Married & 167 & 55.7 \\
\hline \multicolumn{3}{|l|}{ Education Level } \\
\hline Primary School & 20 & 6.7 \\
\hline Secondary School & 101 & 33.7 \\
\hline Higher Institution & 179 & 59.7 \\
\hline \multicolumn{3}{|l|}{ Working Sector } \\
\hline Government & 50 & 16.7 \\
\hline Private & 125 & 41.7 \\
\hline Self-Employed & 65 & 21.7 \\
\hline Jobless & 60 & 20.0 \\
\hline \multicolumn{3}{|l|}{ Monthly Income } \\
\hline RM 1000 and below & 12 & 4.0 \\
\hline RM 1001- RM 2000 & 72 & 24.0 \\
\hline RM 2001-RM 3000 & 55 & 18.3 \\
\hline RM 3001 and above & 100 & 33.3 \\
\hline Not relevant & 61 & 20.3 \\
\hline \multicolumn{3}{|l|}{ Type Of Motorcycle } \\
\hline \multicolumn{3}{|l|}{ Licence } \\
\hline Full Licence & 223 & 74.3 \\
\hline Probation Licence $(\mathrm{P})$ & 30 & 10.0 \\
\hline Learning Licence (L) & 1 & 0.3 \\
\hline No Licence & 46 & 15.3 \\
\hline \multicolumn{3}{|c|}{ Riding Experience (Years) } \\
\hline Less than 2 years & 8 & 2.7 \\
\hline $2-5$ years & 59 & 19.7 \\
\hline $6-9$ years & 43 & 14.3 \\
\hline 10 years and above & 190 & 63.3 \\
\hline \multicolumn{3}{|l|}{ Experience Respondent } \\
\hline \multicolumn{3}{|l|}{ Towards Road accident } \\
\hline Yes & 208 & 69.3 \\
\hline No & 92 & 30.7 \\
\hline \multicolumn{3}{|c|}{ Frequency of Respondents } \\
\hline \multicolumn{3}{|c|}{ Experiencing Road } \\
\hline \multicolumn{3}{|l|}{ Accidents. } \\
\hline 1 times & 52 & 17.3 \\
\hline 2 times & 46 & 15.3 \\
\hline 3 times and more & 110 & 36.7 \\
\hline \multicolumn{3}{|l|}{ Type of Helmet possesed } \\
\hline Full Face & 8 & 2.7 \\
\hline Full Shell & 283 & 94.3 \\
\hline Half Shell & 9 & 3.0 \\
\hline
\end{tabular}


The result obtained is .795 . Therefore, it is indicated that the data is reliable and valid enough. Table 2 shows the correlation between variables is correlated and significant for a few variables.

\subsection{Structural equation modelling}

The result of confirmatory factor analysis $(\mathrm{CFA})$ for proposed model $\left[\chi^{2}(\mathrm{~N}=300, \mathrm{df}=132)=329.519\right.$, $\mathrm{p}<.05]$ is insignificant indicated that the model proposed is good fit for the data. The proposed model (TAM) showed that the goodness of fit indices NFI (.921), GFI (.901), IFI (.951), TLI (.936) and CF1 (.951) are greater than .90. While RMSEA value is .071. Chua [14] indicated that the goodness of fit indices must be greater than .90 while RMSEA value must lower than $<1.0$ for the excellent fit. These result verify the reliability of the model structure to predict behavioral intention to use SHR towards helmet use among motorcyclist. The Square multiple correlation (SMC) showed the highest variation percentage (72\%) which indicate that the amount of construct variables was able to be explained in the model [11].

\subsection{Hypothesis testing}

Based on the analysis result that presented in figure 1, the full structural model was tested using the SEM. Perceived Usefulness $(\beta=.50, \mathrm{p}<0.001)$ and Social Norm $(\beta=.20, \mathrm{p}<0.001)$ are positively associated with behavioral intention to use SHR system. Thereby supporting H1 and H4. In addition, Social Norm $(\beta=.20, p<0.001)$ is significant towards Perceived Usefulness and supporting H5. The path analysis between perceived usefulness and Perceived Ease of Use $(\beta=.86, p<0.001)$ shows that the stronger and positive effect between these two variables. Therefore, $\mathrm{H} 2$ are accepted.

Table 2. Correlation between variables.

\begin{tabular}{ccccccc}
\hline & PS & SN & PU & PEOU & BI & HU \\
\hline PS & 1 & & & & & \\
SN & $.426^{* *}$ & 1 & & & & \\
PU & $.633^{* *}$ & -.002 & 1 & & & \\
PEOU & $.610^{* *}$ & $-.147^{*}$ & $.665^{* *}$ & 1 & & \\
BI & $.637^{* *}$ & $.161^{* *}$ & $.629^{* *}$ & $.586^{* *}$ & 1 & \\
HU &.-0.86 & $.353^{* *}$ & .032 & -.066 & .059 & 1
\end{tabular}

PS: Perceived Safety, SN: Social Norm, PU: Perceived Usefulness, PEOU: Perceived Ease of Use, BI: Behavioral Intention, HU: Helmet Use. **Correlation significant at 0.01 level (2-tailed)

\section{Conclusions}

Safety helmet is the best protective and most effective for motorcyclist during riding. However, the function of safety helmet is meaningful if the motorcyclist use their safety helmet in a proper way. Therefore, a novel solution, Safety Helmet Reminder System (SHR) was introduced to mitigate this problem. Based on the result obtained, perceived usefulness, perceived ease of use and social norm are significant towards behavioral intention to use Safety helmet reminder system (SHR). This indicated that, most of respondent believes that SHR can enhances their performance and make them free from effort. Besides that, they believes that other people opinion is important for them to use the SHR system. However, based on the result obtained, perceived safety are insignificant towards behavioral intention to use SHR system which indicates that perceived safety does not affected towards behavioral intention to use SHR system among motorcyclist. 


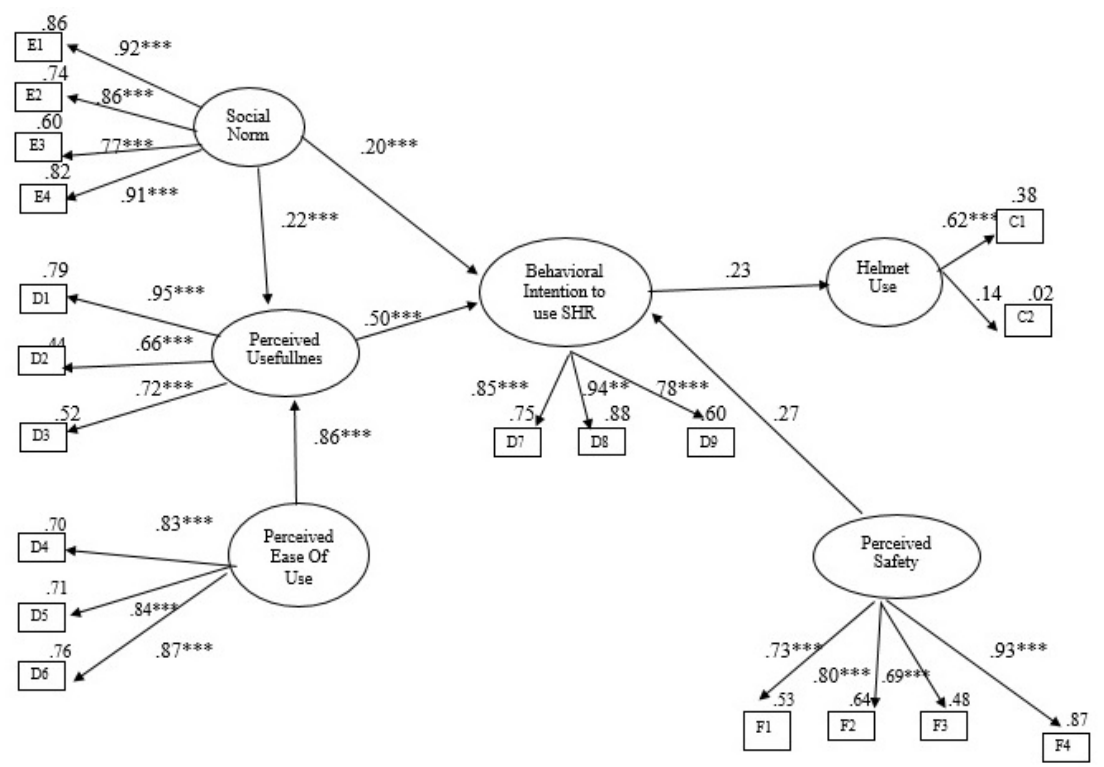

Figure 1. TAM model proposed to predict behavioral intention to use SHR $(* * * p<0.001)$.

\section{References}

[1] S. Mc. Inally, A model for motorcycle rider skill development, L. Dorn (Ed), Driver Behavior and Trainning, Ashgate Publishing, Cranfield University, 35-43, (2003).

[2] M.M.A. Manan and A. Vrhelyi, Motorcycle fatalities in Malaysia, IATSS Research, 36, 30-39, (2012).

[3] M.A. Akaateba, A.R. Gyimah and I. Yakubu, A cross-sectional observational study of helmet use among motorcyclists in Wa. Ghana, Accident Analysis and Prevention, 64, 18-22, (2014).

[4] K. Ambak, A. Riza Atiq and I. Rozmi, Intelligent transport system for motorcycle safety and issues, European J. of Scientific Research, 28 (4), 600-611, (2009).

[5] Polis Diraja Malaysia, Laporan Perangkaan Malaysia 2010, Malaysia, (2012).

[6] T.Y. Pang, R.S. Radin Umar, A.A. Azhar, M.T. Mohd Nasir and H.H Hamdan, Injury characteristic of motorcyclist by Abbreaviated Injury Scale (AIS), Research Report 2/2000, National Road Safety Council Malaysia, Kuala Lumpur, (2000).

[7] F.A.O. Fernandez and R.J. Alves De Sousa, Motorcycle helmets- A state of the art review, Accident Analysis and Prevention, 56, 1-21, (2013).

[8] T.R. Jaafar, M.F. Mustafa, S. kemin and R. Kasiran, Kemalangan jalan raya: Analisis data membabitkan pengguna motosikal, Jurnal Teknologi, 38(B), 1-14, (2003).

[9] S.P. Baker, B. O'Neill, M.J. Ginsburg and L. Guohua, The Injury Fact Book, Oxford University Press, New York, (1992).

[10]F.D. Davis, Perceived usefulness, perceived ease of use, and user acceptance of information technology, MIS Quarterly, 13, 319-340, (1989).

[11]K. Ambak, R. Ismail, R.A. Abdullah, A.A. Latif and M.E. Sanik, Application of technology acceptance model in predicting behavioral intention to use safety helmetreminder system, Research J. of Applied Science, Engineering and Technology, 5(3), 881-888, (2013).

[12]R.H. Shroff, C.C. Deneen and E.M.W. Ng, Analysis of the technology acceptance model in examining students' behavioral intention to use an e-portfolio sytem. Autralasian, J. of Education Technology, 27(4), 600-618, (2011).

[13] S. Osswald, D. Wurhofer and S. Trosterer, Predicting information technology usage in the car: Towards a car technology aceptance model, Automotive U1'12, Portsmouth, (2012). 
[14]R. Weston and P.A. Jr. Gore, A brief guide to structural equation modelling, Couns. Psychol, 34(5), 719-751, (2006).

[15]K. Ambak, R. Ismail, R.A. Abdullah, M.N. Borhan, Using structural equation modelling and the behavioral sciences theories in predicting helmet use, Proceeding Of the Int. Conference on Andvances Sciences, Engineering and Information Technology, Putrajaya, 639-645, (2011).

[16]K. Ambak, N. Rosli, B.D. Daniel and J. Prasetijo, Behavioral intention to use safety helmet reminder system using the extended technology acceptance model, The 3rd Annual Int. Conference on Architecture and Civil Engineering, Singapore, (2015).

[17] Y. P. Chua, Kaedah dan Statistik, Uian Regresi, Analisis Faktor dan Analisis SEM, McGraw Hill, Malaysia, (2014). 